\title{
Dichloroacetic acid-induced testicular toxicity in male rats and the protective effect of date fruit extract
}

\author{
Amira El Arem ${ }^{1 *}$, Lamia Lahouar ${ }^{1}$, Emna Behija Saafi ${ }^{1}$, Amira Thouri ${ }^{1}$, Fatma Ghrairi ${ }^{1}$, Zohra Houas ${ }^{2}$, \\ Fadoua Neffati ${ }^{3}$ and Lotfi Achour ${ }^{1 *}$
}

\begin{abstract}
Background: The present study was designed to investigate the protective effect of aqueous date extract (ADE) against the dichloroacetic acid (DCA)-induced testicular injury in rats.

Methods: Forty-eight male Wistar rats were randomly divided into six groups of eight: group I served as the control; group II was given ADE $(4 \mathrm{ml} / \mathrm{kg})$ by gavage; groups III and IV received DCA at 0.5 and $2 \mathrm{~g} / \mathrm{L}$ drinking water, respectively; and groups $V$ and $V I$ received DCA at 0.5 and $2 \mathrm{~g} / L$ drinking water, respectively, before ADE administration. The experiment was performed for two months.

Results: Results showed that the absolute weights of testes and epididymis were decreased following the DCA administration. The testosterone, FSH and LH levels were also decreased. Severe histopathological changes in testes were observed including degeneration of seminiferous tubules and depletion of germ cells. These changes were associated with alterations of oxidative stress markers. Levels of lipid peroxidation and SOD and CAT activities were increased, while activity of GPx and GSH levels were decreased. Pretreatment with ADE has effectively alleviated the oxidative stress induced by DCA thereby restoring these parameters to normal values.
\end{abstract}

Conclusions: These results suggest that ADE has a protective effect over DCA-induced oxidative damage in rat testes.

Keywords: Date extract, Dichloroacetic acid, Male reproductive, Oxidative stress, Rats

\section{Background}

In recent years, there has been growing concern about the deleterious effects of chemicals on developing male reproductive system thereby perturbing the testicular milieu. Despite the low oxygen tensions that characterize the testicular microenvironment, this tissue remains vulnerable to oxidative stress due to the abundance of highly unsaturated fatty acids (particularly 20:4 and 22:6) and the presence of potential reactive oxygen species (ROS)- generating system [1]. The ROS generated during normal testicular function plays an important role in regulating the function of the testes. Although ROS are known to have damaging effects, controlled,

\footnotetext{
* Correspondence: amira.arem@yahoo.fr; lotfiachour@yahoo.fr

${ }^{1}$ Laboratory of Bioressources, Biology Integrative and Valorization, Higher Institute of Biotechnology of Monastir, University of Monastir, Avenue Tahar Hadded, BP 74, 5000 Monastir, Tunisia

Full list of author information is available at the end of the article
}

low levels of ROS play a beneficial role in normal testicular function. Conversely, increased levels of ROS can be detrimental to testicular function. To overcome this, the testis is equipped with a very potent antioxidant system that protects it from the damaging effects of ROS. The glutathione family of proteins, superoxide dismutase, catalase and several non-enzymatic antioxidants all help the testes by counteracting any oxidative impact [1]. However, overexposure to environmental toxicants has been shown to impair the pro-oxidant/ antioxidant balance in the testes and thereby hamper testicular function [2].

Dichloroacetic acid (DCA) is one of the most important toxic disinfectant by-products formed during water chlorination. This compound was used in agriculture as a fungicide and consequently was detected in vegetables, fruits, and grains [3] and can be taken up into foodstuffs from the cooking water [4]. Therefore, human exposures 
to this compound can occur via food consumption. In another way, DCA was used clinically for therapeutic purposes, especially for the treatment of lactic acidosis in patients with mitochondrial dysfunction $[5,6]$. However, long-term treatment of patients with a certain dose $(10-50 \mathrm{mg} / \mathrm{kg} /$ day $)$ of DCA was found to be associated with adverse effects that included mild liver dysfunction, hypoglycemia and changes in the central and peripheral nervous system $[5,6]$.

Furthermore, there is an extensive and consistent data base demonstrating the reproductive toxicity of chronic DCA treatment in male including polyneuropathy and testicular degeneration [7-10].

Several studies were carried out to evaluate the potential role of antioxidants, such as synthetic or isolated from medicinal plants, for the protection of cells against oxidative damage and reproductive toxicity due to environmental toxins [11-15]. These substances have shown their effectiveness to attenuate the oxidative damage, lipid peroxidation, and toxic effects produced in a wide array of systems, organs, and tissues.

Date palm (Phoenix dactylifera L.) is one of the oldest trees dating from 6000 years. The various parts of this plant are widely used in traditional medicine for the treatment of various disorders [16, 17]. Date fruits are the most commonly used part due to their richness in several nutrients (dietary fibers, sugars, vitamins, proteins, fat), beside to their dietary antioxidants (flavonoids, phenolic acids, sterols, anthocyanins, carotenoids, tanins, selenium, zinc, magnesium). These fruits are consumed at any of the three major stages of maturity such as besser or khalal (fresh, hard ripe, color stage), rutab (crisp to succulent or ripe stage), or tamr (soft pliable, full ripe stage). The information accrued in the past four decades suggest that dates possess diverse medical uses including antihyperlipidemic, anti-cancer, anti-inflammatory, gastroprotective, hepatoprotective and nephroprotective activities and thereby serving as an important healthy food in the human diet [16]. In traditional medicinal practices, dates are considered as tonic and aphrodisiac [18]. Despite several studies have tested the repro-protective effect of date pits and pollen extracts and aqueous fruit extract of mature date fruits [19-23], no study has been reported in the preventive effect of date fruit at besser stage.

For this reason, this study was carried out to determine the effect of subchronic exposure to two carcinogenic doses (0.5 and $2 \mathrm{~g} / \mathrm{l})$ [24, 25] of dichloroacetic acid on the reproductive system of male rats and to assess whether these effects can be ameliorated by pretreatment with aqueous date extract of date fruit, at besser stage.

\section{Methods}

\section{Date palm fruit extract preparation}

The Degla variety was collected from the station of Souk Lahad (Kebili, Tunisia) at besser stage of maturation. The flesh was manually separated from the pits, soaked in distilled water (1:3 ratio, weight to volume) and kept for $48 \mathrm{~h}$ at a temperature of $4{ }^{\circ} \mathrm{C}$. Then the mixture was centrifuged at $4{ }^{\circ} \mathrm{C}$ for $20 \mathrm{~min}$ at $4000 \times g$, and the supernatant was collected [26].

\section{Experimental design}

Forty-eight male Wistar rats weighing 180-200 g were obtained from Central Pharmacy of Tunis, Tunisia. Animals were divided into six equal groups of eight each and were housed under standard laboratory conditions with a 12-h light-dark cycle at constant temperature $\left(22 \pm 2{ }^{\circ} \mathrm{C}\right)$ and humidity $(55 \pm 5 \%)$ and kept on commercial diet and tap water provided adlibitum. The animals were handled according to the guidelines of the Tunisian Society for the Care and Use of Laboratory Animals, and the study was approved by the University of Tunisia Ethical Committee (approval number: FST/LNFP/Pro 152012).

After the acclimatization period, the groups were assigned at random to one of the following treatments: group 1 served as control receiving saline (0.9\%), group 2 received a daily oral dose $(4 \mathrm{ml} / \mathrm{kg})$ of aqueous date extract (ADE), groups 3 and 4 were orally treated respectively with dichloroacetic acid at $0.5 \mathrm{~g} / \mathrm{l}(\mathrm{DCAC} 1)$ and DCA at $2 \mathrm{~g} / \mathrm{l}$ (DCAC2) as drinking water, while groups 5 and 6 received $\mathrm{ADE}$ plus DCAC1 or DCAC2. All the animals were observed daily for the presence of clinical signs of toxicity during the two months of the study.

\section{Sample collection}

After 2 months of the treatment period, rats were anesthetized by inhalation of diethyl ether, and blood was drawn by cardiac puncture and collected into silicon disposable glass tubes with EDTA as an anticoagulant. Tubes were centrifuged at $4000 \mathrm{~g}$ for $15 \mathrm{~min}$ at $4{ }^{\circ} \mathrm{C}$. The plasma samples were stored at $-20{ }^{\circ} \mathrm{C}$ in aliquots until analysis. Testes and epididymis were excised immediately washed with an ice-cold physiologic saline solution $(0.9 \%, w / v)$, blotted dry and weighed. About $1 \mathrm{~g}$ of one testis was cut into small pieces, homogenized with an Ultra Turrax homogenizer T25 (Cole-Parmer) in 3 volumes of ice-cold appropriate buffer (TBS, pH 7.4) and centrifuged at $9000 \mathrm{~g}$ for $15 \mathrm{~min}$ at $4{ }^{\circ} \mathrm{C}$. Supernatants were collected, aliquoted and stored at $-80^{\circ} \mathrm{C}$ until use for enzyme assays and lipid peroxidation. Bradford's [27] method was used to determine the protein content.

\section{Plasma levels of $\mathrm{FSH}, \mathrm{LH}$ and testosterone}

The plasma FSH and $\mathrm{LH}$ were determined by radioimmunoassay (RIA) using reagents from a commercial 
kit (SBTesto,CIS BioInternational, Gif-sur-Yvette, France). Plasma levels of testosterone were determined by a competitive radioimmunoassay kit (Immunotech, Beckman Coulter, France) using 125I-labeled testosterone analog as the radioactive marker. The monoclonal antibody used in the immunoassay was highly specific for testosterone. The assay was performed as per the manufacturer's instructions. The amount of radioactive exogenous testosterone bound to the antibody is inversely proportional to the concentration of the endogenous testosterone present.

\section{Antioxidant status and lipid peroxidation}

Superoxide dismutase (SOD) activity was assayed spectrophotometrically as described by Beyer and Fridovich [28]. This method is based on the capacity of SOD to inhibit the oxidation of nitrobluetetrazolium (NBT). One unit of SOD represents the amount of enzymes required to inhibit the rate of NBT oxidation by $50 \%$ at $25{ }^{\circ} \mathrm{C}$. The activity was expressed as units/mg protein.

Catalase (CAT) activity was measured by the UV colorimetric method of Aebi [29] using $\mathrm{H}_{2} \mathrm{O}_{2}$ as substrate. One unit of CAT activity is equal to the $\mu \mathrm{mol}$ of $\mathrm{H}_{2} \mathrm{O}_{2}$ destroyed/min/mg proteins.

Glutathione peroxidase (GPx) activity was assayed according to the method of Flohe and Gunzler [30]. The activity was expressed as $\mu \mathrm{mol}$ of GSH oxidized $/ \mathrm{min} / \mathrm{mg}$ of protein, at $25^{\circ} \mathrm{C}$.

Reduced glutathione (GSH) level was measured colorimetrically as protein-free sulfhydryl content using 5,5-dithiobis-2-nitrobenzoic acid (DTNB) according to the method of Sedlak and Lindsay [31]. The values were expressed as $\mu \mathrm{mol} / \mathrm{mg}$ proteins.

Lipid peroxidation (LPO) was determined indirectly by measuring the production of malondialdehyde (MDA) in the testes extract according to the method of Buege and Aust [32] based on TBA reactivity. The absorbance was measured at $530 \mathrm{~nm}$ and was proportional to the amount of TBARS formed. The results were expressed as nmol MDA equivalents/mg protein.

\section{Histological examination}

One testis of each rat was removed and quickly fixed in $10 \%$ buffered-neutral formalin, routinely processed, embedded in paraffin and sections of $5 \mu \mathrm{m}$ thick were cut. Hematoxylin and eosin $(\mathrm{H} \& \mathrm{E})$ were used for staining [33]. The histological examination was observed at the light microscopic level. The sections were analyzed by a certified pathologist ignoring the sample assignments to experimental groups. A minimum of three fields of each testis slide were morphologically evaluated.

\section{Statistical analysis}

All experimental data were expressed as mean \pm standard deviation. The statistical analysis was done by one-way analysis of variance (ANOVA) followed by Duncan's test using SPSS 11.0 for Windows. Statistical significance was set at $p<0.05$.

\section{Results}

\section{Testes and epididymis weights}

Weights of testes and epididymis, expressed as absolute body weight, in rats after DCA administration was found to be significantly decreased, compared with the control group (Fig. 1). This decrease was more induced with the higher dose of DCA $(2 \mathrm{~g} / \mathrm{L})$. However, pretreatment with the ADE restored the absolute testicular and epididymis weights as compared to DCA intoxicated rats.

\section{Serum FSH, LH and testosterone levels}

The effects of ADE on plasma FSH, LH and testosterone levels are shown in Table 1. DCA administration in rats for 2 months induced significant dose-dependent decreases $(p<0.05)$ in these hormonal levels as compared to control group. Alterations of these hormones were significantly reversed $(p<0.01)$ by pretreatment with the $\mathrm{ADE}$ comparatively to DCA intoxicated groups. No

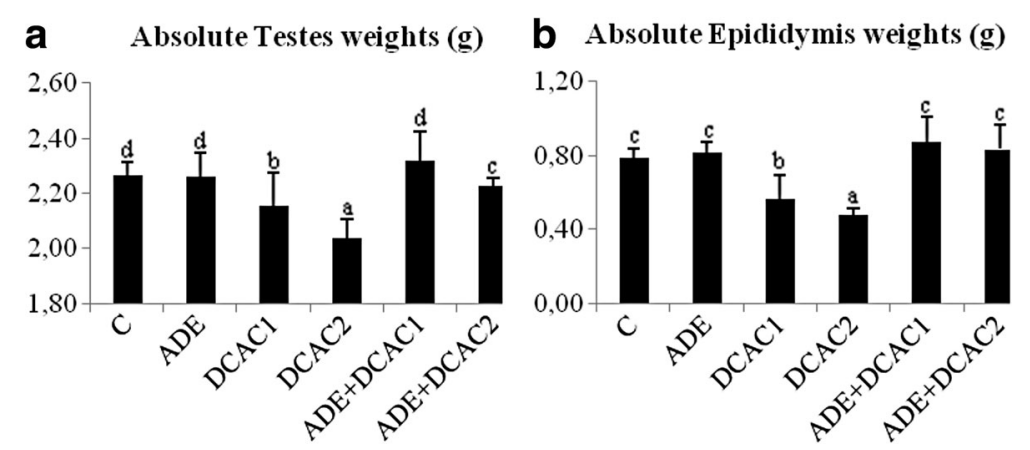

Fig. 1 Effect of ADE on reproductive organs weights ((a) testis and (b) epididymis) in male rats treated with two different doses of DCA (0.5 and $2 \mathrm{~g} / \mathrm{l})$. Different letters (a-d) indicate significant differences between groups at $p<0.05$ by Duncan's test. ADE: aqueous date extract, DCAC1: dichloroacetic acid at $0.5 \mathrm{~g} / \mathrm{l}, \mathrm{DCAC2}$ : dichloroacetic acid at $2 \mathrm{~g} / \mathrm{l}$ 
Table 1 Effect of ADE on plasma levels of FSH, LH and testosterone in male rats treated with two different doses of DCA

\begin{tabular}{lcll}
\hline & Testosterone $(\mathrm{ng} / \mathrm{ml})$ & FSH $(\mathrm{mlU} / \mathrm{ml})$ & $\mathrm{LH}(\mathrm{mlU} / \mathrm{ml})$ \\
\hline $\mathrm{C}$ & $3.45 \pm 0.10 \mathrm{c}$ & $3.20 \pm 0.02 \mathrm{c}$ & $1.29 \pm 0.01 \mathrm{c}$ \\
ADE & $3.46 \pm 0.07 \mathrm{c}$ & $3.19 \pm 0.01 \mathrm{c}$ & $1.28 \pm 0.01 \mathrm{c}$ \\
DCAC1 & $2.30 \pm 0.28 \mathrm{~b}^{\mathrm{a}}$ & $2.94 \pm 0.09 \mathrm{~b}$ & $1.18 \pm 0.01 \mathrm{~b}$ \\
DCAC2 & $1.81 \pm 0.17 \mathrm{a}^{\mathrm{a}}$ & $2.19 \pm 0.05 \mathrm{a}^{\mathrm{a}}$ & $0.80 \pm 0.01 \mathrm{a}^{\mathrm{a}}$ \\
ADE+ DCAC1 & $3.30 \pm 0.32 \mathrm{c}$ & $3.17 \pm 0.02 \mathrm{c}$ & $1.28 \pm 0.01 \mathrm{c}$ \\
ADE+ DCAC2 & $2.96 \pm 0.03 \mathrm{c}$ & $3.08 \pm 0.03 \mathrm{bc}$ & $1.22 \pm 0.01 \mathrm{c}$ \\
\hline
\end{tabular}

Values are mean $\pm S D$ of eight rats in each group. Different letters (a-c) indicate significant differences between groups at $p<0.05$. C: control, $A D E$ aqueous date extract, DCAC1: dichloroacetic acid at $0.5 \mathrm{~g} / \mathrm{l}, \mathrm{DCAC2}$ : dichloroacetic acid at $2 \mathrm{~g} / \mathrm{l}$

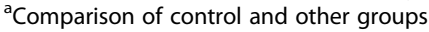

significant $(p>0.05)$ changes were observed in rats treated with the $\mathrm{ADE}$ alone.

\section{Antioxidant status and lipid peroxidation levels}

Results of testicular antioxidant status and lipid peroxidation have been depicted in Table 2. The exposure of rats to DCA for 2 months caused a significant $(p<0.05)$ dose-dependent increase in testes SOD and CAT activities and LPO and a significant $(p<0.05)$ dose-dependent decrease of GPx activity and GSH levels compared with those of control group. These alterations were more marked with the higher DCA dose (approximately by 2 fold). However, pretreatment with ADE improved significantly $(p<0.05)$ these parameters. ADE alone did not produce any significant changes in enzymes antioxidant activity, LPO and GSH levels.

\section{Histological examination}

Light microscopic examinations of the testicular sections of the control rats and those receiving $\mathrm{ADE}$ alone showed normal histoarchitecture that consisted of uniform, wellorganized seminiferous tubules with complete spermatogenesis and normal interstitial connective tissue (Fig. 2a, b ). The testicular tissue of rats received DCA alone showed degenerative changes of the majority of the seminiferous tubules (Figs. 3 and 4). Treatment of rats with DCA at
0.5 g/l (Fig. 3 a, b, c) caused extensive degeneration in some tubules and depletion of germ cells and Leydig cells, vacuolation of epithelium cells and disintegration of the spermatogenic cells, and necrosis in some other seminiferous tubules. Regarding the interstitium, there were dilation and congestion of the interstitial blood vessels and mild edema. These alterations were more accentuated in rats treated with DCA at $2 \mathrm{~g} / \mathrm{L}$ (Fig. 4). These rats were characterized by reduced and disorganized seminiferous tubules, distorted basement membrane, greatly depleted of germ cells and incomplete spermatogenesis. Moreover, the seminiferous tubules were almost devoid of spermatids and spermatozoa and showed cytoplasmic vacuolation. Vacuolar degeneration of spermatogonia, spermatocyte I and Sertoli cells was evident. Necrotic cells in the lumina of most seminiferous tubules were abundant. Marked dilation and congestion of blood vessels were noticed in the interstitial spaces. Hyperplasia of Leydig cells was detected in the interstitial tissue; there was crowding of Leydig cells forming dense clumps that surround most of the seminiferous tubules. Conversely, testes of rats pretreated with $\mathrm{ADE}$ revealed a marked repairing of testicular abnormalities induced by DCA at $0.5 \mathrm{~g} / \mathrm{l}$ near to control group (Fig. 5a). However, those pretreated with ADE and receiving DCA at 2 g/l (Fig. 5b) showed mild interstitial edema and slight vacuolization of the germinal epithelial cells. A few numbers of seminiferous tubules had shown necrotic germinal epithelium in their lumina. There was a marked improvement of spermatogenesis, evidenced by the presence of elongated spermatids and spermatozoa in the majority of seminiferous tubules.

\section{Discussion}

The subchronic treatment of rats with DCA at both concentrations of 0.5 and $2 \mathrm{~g} / \mathrm{l}$ (corresponding to 33.78 and $131.24 \mathrm{mg} / \mathrm{kg} /$ day, respectively) during two months induced dose-dependent decreases in absolute testes and epididymis weights. These results are in agreement with those found in previous studies [9, 10, 34, 35] using different concentrations of DCA during different

Table 2 Effect of ADE on testicular antioxidant enzymes activities and GSH and LPO levels in male rats treated with two different doses of DCA

\begin{tabular}{|c|c|c|c|c|c|}
\hline & $\begin{array}{l}\mathrm{CAT}\left(\mu \mathrm{mol} \mathrm{H}_{2} \mathrm{O}_{2} / \mathrm{min} / \mathrm{mg}\right. \\
\text { proteins) }\end{array}$ & $\begin{array}{l}\mathrm{SOD}(\mathrm{U} / \mathrm{mg} \\
\text { proteins) }\end{array}$ & $\begin{array}{l}\text { GPx ( } \mu \mathrm{mol} \text { GSH oxidized/ } \\
\mathrm{min} / \mathrm{mg} \text { proteins) }\end{array}$ & $\begin{array}{l}\mathrm{GSH}(\mu \mathrm{mol} / \mathrm{mg} \\
\text { proteins) }\end{array}$ & $\begin{array}{l}\mathrm{LPO} \text { (nmol MDA/mg } \\
\text { proteins) }\end{array}$ \\
\hline C & $191.47 \pm 8.95 \mathrm{a}$ & $3.03 \pm 0.29 a$ & $11.36 \pm 0.93 c$ & $0.36 \pm 0.01 \mathrm{c}$ & $1.08 \pm 0.03 a$ \\
\hline ADE & $184.62 \pm 11.14 a$ & $3.09 \pm 0.35 a$ & $11.61 \pm 0.80 c$ & $0.37 \pm 0.04 c$ & $1.08 \pm 0.07 a$ \\
\hline DCAC1 & $277.48 \pm 12.17 c^{a}$ & $4.13 \pm 0.53 b^{a}$ & $10.81 \pm 0.79 b$ & $0.26 \pm 0.04 b^{a}$ & $1.84 \pm 0.11 c^{a}$ \\
\hline DCAC2 & $370.04 \pm 12.75 d^{a}$ & $5.31 \pm 0.46 c^{a}$ & $9.37 \pm 0.76 a^{a}$ & $0.18 \pm 0.03 a^{a}$ & $2.39 \pm 0.16 d^{a}$ \\
\hline $\mathrm{ADE}+\mathrm{DCAC1}$ & $192.28 \pm 10.36 a$ & $3.31 \pm 0.32 a$ & $11.62 \pm 0.58 c$ & $0.36 \pm 0.05 c$ & $1.14 \pm 0.06 a$ \\
\hline $\mathrm{ADE}+\mathrm{DCAC2}$ & $215.79 \pm 13.09 a b$ & $3.99 \pm 0.50 \mathrm{ab}$ & $11.16 \pm 0.99 c$ & $0.30 \pm 0.04 b c$ & $1.26 \pm 0.03 \mathrm{ab}$ \\
\hline
\end{tabular}

Values are mean \pm SD of eight rats in each group. Different letters (a-c) indicate significant differences between groups at $p<0.05$. C: control, ADE aqueous date extract, DCAC1: dichloroacetic acid at $0.5 \mathrm{~g} / \mathrm{l}, \mathrm{DCAC2}$ : dichloroacetic acid at $2 \mathrm{~g} / \mathrm{l}, \mathrm{LPO}$ : lipid peroxidation

${ }^{a}$ Comparison of control and other groups 


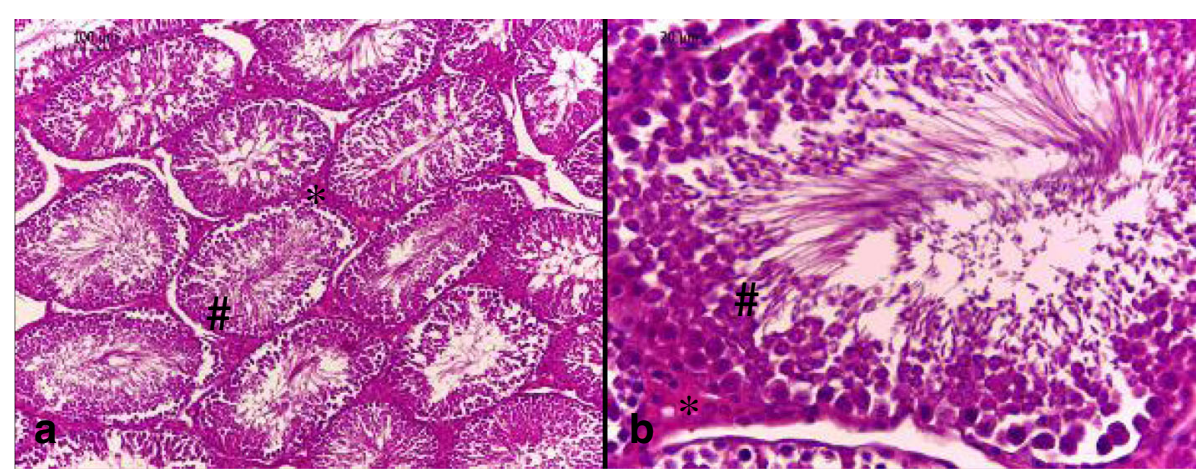

Fig. 2 Testis section of control and ADE treated groups showing (a) normal histological architecture pattern of seminiferous tubules with (b) normal germ cells (\#) and interstitial connective tissue $\left(^{*}\right)\left(H \& E_{1}\right.$ (a) 100X and (b) 400X)

treatment periods in rat and dogs. The weight of the testicles is largely dependent on the mass of the differentiated spermatogenic cells. Thus a reduction in its weight might be due to the decreased number of germ cells and inhibition of spermatogenesis and steroidogenic enzyme activity $[12,36]$. In fact, different studies $[7,9,10]$ demonstrated that repeated administration of DCA to animal induced, in a dose-dependent way, testicular damage associated with spermatogenic damage and germinal epithelial degeneration. These findings are confirmed in our study by histopathological lesions. A previous study has shown that the pathological changes of seminiferous epithelium may cause the disruption of Sertoli and germ cells, which results in impaired spermatogenesis and may also lead to germ cell loss [37].

It is known that normal spermatogenesis depends on the testosterone secretion and gonadotropic hormonal action of the pituitary gonadotropins such as luteinizing hormone and follicle stimulating hormone. LH stimulates testosterone production and secretion by Leydig cells, while FSH acts directly on the seminiferous tubules [38, 39]. Contrary to the study of Linder et al. [10] which reported no effect on testosterone levels in rats intoxicated for 14 consecutive days at 18 to $1440 \mathrm{mg} \mathrm{kg} / \mathrm{b} . \mathrm{w}$, we observed a significant decrease of testosterone levels at $131.24 \mathrm{mg} / \mathrm{kg}$ b.w dose of

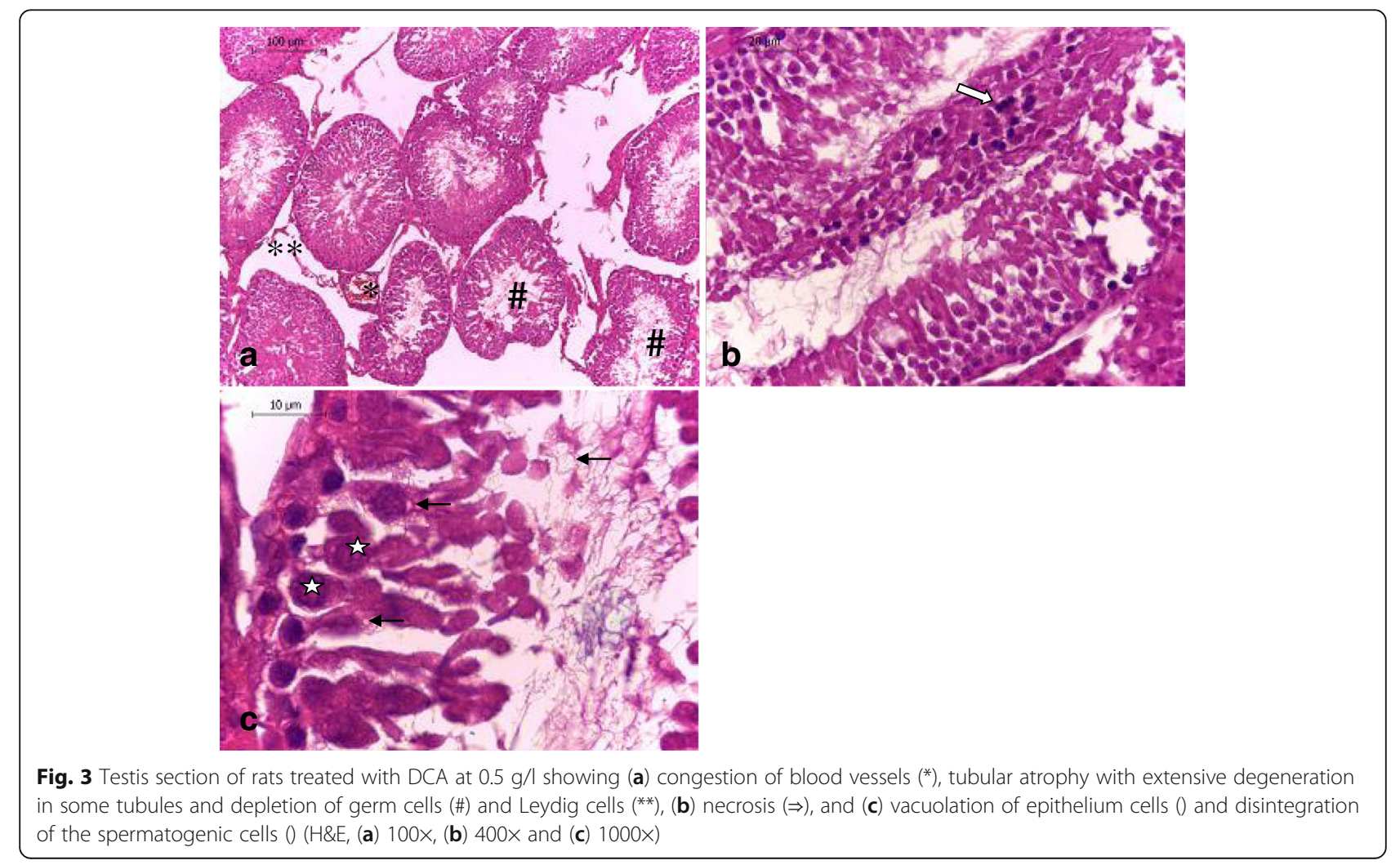




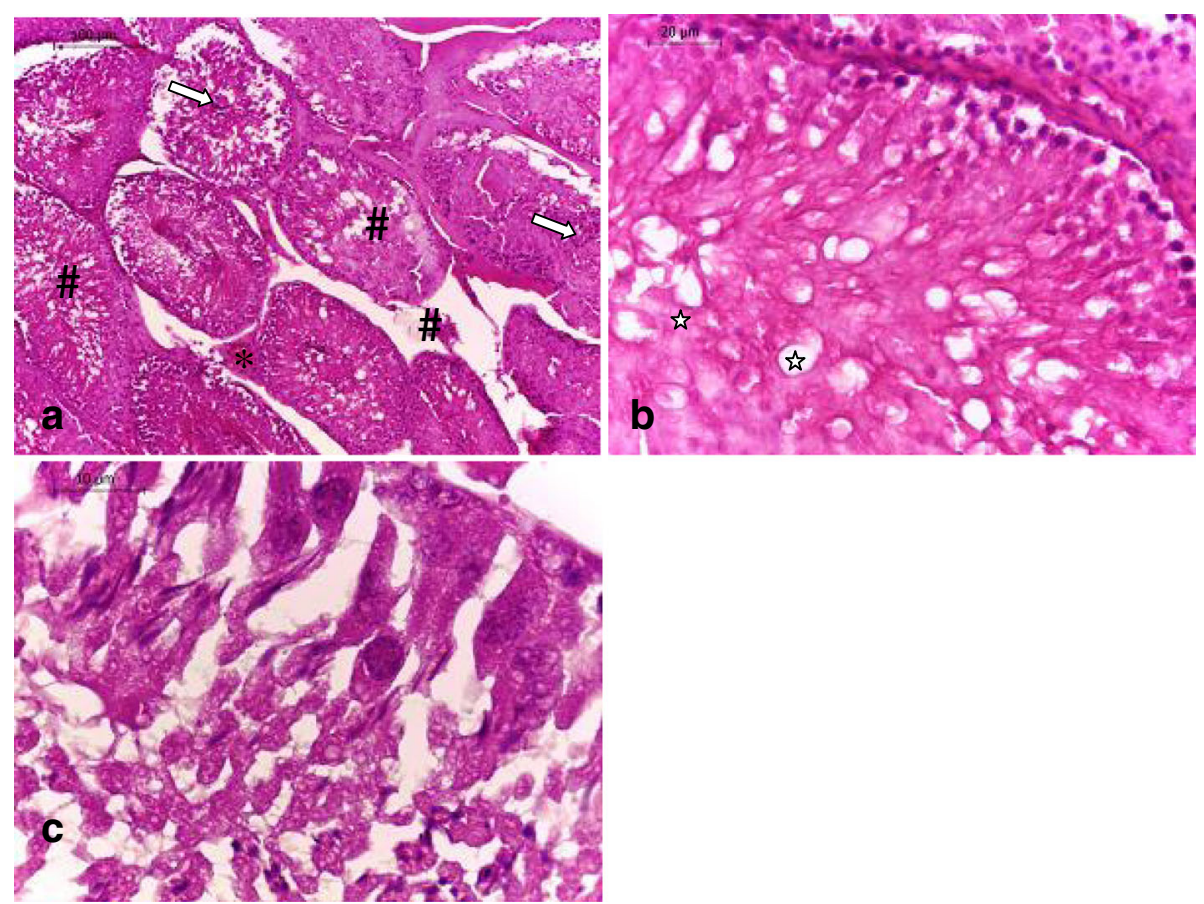

Fig. 4 Testis section of rats treated with DCA at $2 \mathrm{~g} / \mathrm{l}$ showing marked disturbances of the normal architecture of the testicular tissues; (a) congestion of blood vessels 0, hyperplasia of seminiferous epithelium and Leydig cells (\#), necrotic cells in the lumina $(\Rightarrow)$, (b) cytoplasmic vacuolation and edema 0, and (c) necrotic and vacuolar degeneration of spermatogonia, spermatocyte I and sertoli cells was evident (H\&E, (a) 100×, (b) 400× and (c) 1000X)

DCA after 2 months of intoxication. These results are similar to those found in rats treated by four trihalomethanes, other water disinfection by-products [40]. These results are also confirmed by the histopathological changes in the number and structure of Leydig cells in DCA-intoxicated rats. Sanghamitra et al. [41] suggested that degeneration of Leydig cell resulted in decreased synthesis of testosterone, which in turn disturbs the process of spermatogenesis. Previous studies have shown that exposure to environmental contaminants adversely affects testicular function by decreasing pituitary LH secretion and reducing Leydig cell steroidogenesis $[42,43]$. In the present study, the subchronic DCA-intoxication induced significant dose-dependent depletion in FSH and LH levels, mostly marked in rats intoxicated with the higher DCA dose $(2 \mathrm{~g} / \mathrm{l})$. These results are in agreement with those found by Klinefelter et al. [44] in rats treated with bromochloroacetic acid. The observed reduction in plasma $\mathrm{LH}$ and FSH levels in DCA-exposed rats suggest that DCA perturbs anterior pituitary hormone synthesis and secretion.

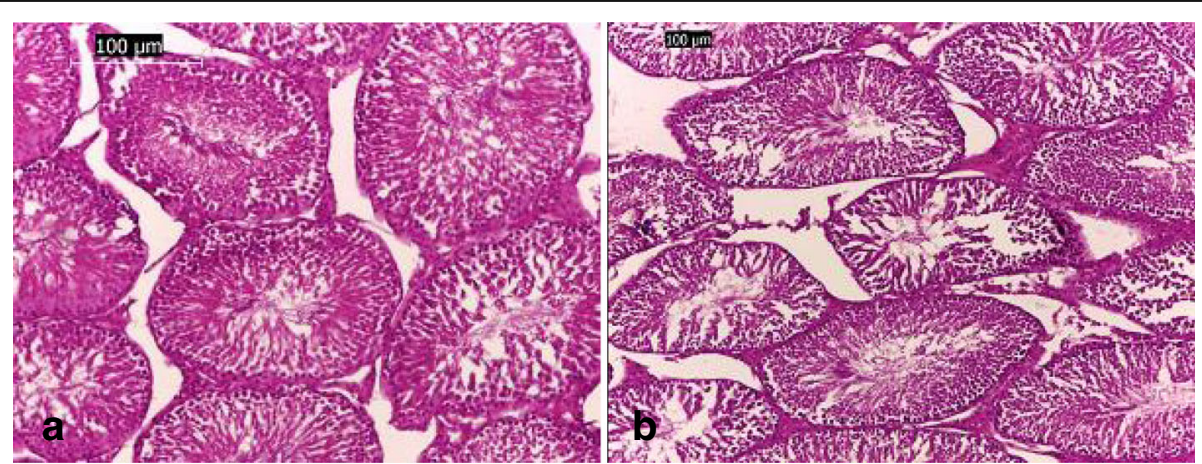

Fig. 5 Testis sections of rats treated with (a) ADE and DCA at 0.5g/l showing significant improvement of histological architecture with normal seminiferous and sertoli cells, and (b) those treated with ADE and DCA at 2g/l showing mild degenerative changes of seminiferous tubules, mild congestion and edema (H\&E, 100X) 
In our previous studies $[45,46]$ we have shown that DCA induced oxidative stress in liver and renal tissues by affecting endogenous antioxidant defense enzymes and lipid peroxidation. In the same way, in this study, we found that DCA induced oxidative stress in testicular tissues illustrated by an alteration in antioxidant enzymes activity and in lipid peroxidation level beside a decrease in GSH level. Antioxidant enzymes represent a defense mechanism, and are responsible for detoxification of reactive oxygen species (ROS). The SOD-CAT system provides the first defense against oxygen toxicity. SOD is considered to be one of the most active enzymes, its activity is sufficient for the dismutation of superoxide anions to hydrogen peroxide $\left(\mathrm{H}_{2} \mathrm{O}_{2}\right)$ produced during oxidative stress in cells [47]. The elimination of $\mathrm{H}_{2} \mathrm{O}_{2}$ is either effected by CAT or GPx, with the latter playing predominating role in the testes [48]. Induction of SOD could occur during high production of superoxide anion. Therefore, an increase in the SOD activity indicates an increase of $\mathrm{O}_{2}^{-}$production. Also, the elevated activity of CAT may due to the adaptive response to the generated free radicals. Thus increased activities of SOD and CAT may serve as protective responses to eliminate reactive free radicals [49]. GPx is involved in catalyzing the reduction of $\mathrm{H}_{2} \mathrm{O}_{2}$ at the expense of reduced GSH [50]. The level of GPx in the DCA-intoxicated rats, namely those receiving the higher dose, was depleted which can be attributed to either increased $\mathrm{H}_{2} \mathrm{O}_{2}$ generation or decreased GSH concentration. Decrease in GSH level as observed in the present study may be due to increased utilization of GSH for metabolism of lipid hydroperoxides by GPx or interaction of GSH with free radicals [13]. Thiol-based antioxidant system is the primary line of defense against oxidative stress. The decreased concentration of GSH increases the sensitivity of organ to oxidative and chemical injury and is one of the primary factors which permit lipid peroxidation. In agreement with this hypothesis is the increase in MDA levels in rats' testes observed in this study. MDA is a major oxidation product of peroxidized polyunsaturated fatty acids and increased MDA content is an important indicator of lipid peroxidation [51]. Therefore the increase in lipid peroxidation is the reflection of damage caused to the membranous structures. These disturbances in antioxidant enzyme and non-enzymatic systems and increases in lipid peroxidation in testes of rats intoxicated with DCA in the present study are in agreement with those induced by different other environment toxicants $[15,52-55]$. Histoarchitecture changes as seen in this study are supported by the significant changes seen in the enzymes and non-enzyme antioxidant defense systems as well as lipid peroxidation, which reflect increased ROS production. Nagda and Bhatt [13] suggested that enhancement of ROS production in the testes may further damage vital components of the cell, like nucleic acids and proteins which further lead to oligozoospermia and abnormal spermatozoa. These findings support the results from other reports that DCA can seriously alter the testicles and reproductive tract in male rats $[7,9,10]$.

Several studies have shown the ability of mature date fruits extract to increase sperm count, sperm motility, and viability [56] and to enhance spermatogenesis and increased the concentration of testosterone, FSH and LH [22] in intoxicated male rats. However, no study has been reported on the repro-protective effect of these fruits at besser stage of maturation. In the present study, the pretreatment with the ADE restored the testes and epididymis weights and histopathological alterations caused by DCA and TCA, in addition to retaining the control values of oxidative stress markers. The observed therapeutic potency of ADE might be due to several contributing factors, primarily including the mineral (zinc, selenium, copper, iron, calcium, cobalt, magnesium, manganese) and the vitamins (A, B, C) composition of these fruits [16]. Zinc is an acknowledged antioxidant factor that as well as being a core constituent of free radical scavenging enzymes such as SOD and a recognized protector of sulfhydryl groups is also thought to impair lipid peroxidation by displacing transition metals such as iron and copper from catalytic sites [57]. Selenium is an antioxidant trace element that is involved in the metabolism of free radicals and other substances produced by the oxidation of lipids in cell membranes. It also plays a role in metabolism in the liver and contributes to the maintenance of skeletal and cardiac muscles and sperm. Selenium is also a component of the majority of glutathione peroxidase antioxidant enzymes that are important in supporting the testicular function [1]. Vitamin C (ascorbic acid) contributes to the support of spermatogenesis at least in part through its capacity to reduce $\alpha$-tocopherol and maintain this antioxidant in an active state [58]. Vitamin C is itself maintained in a reduced state by a GSH-dependent dehydroascorbate reductase, which is abundant in the testes [59]. Deficiencies of vitamins $C$ lead to a state of oxidative stress in the testes that disrupts both spermatogenesis and the production of testosterone [60]. The second mechanism by which aqueous date fruit extract protect testicles may be attributed to their richness in various polyphenolic compounds namely the flavonoids that are highly efficient against ROS-mediated injury [61]. The quercetin, a bioactive flavonoid component, of date fruit at this besser stage [62] may be one of the responsible of this observed protective effect. It was suggested that quercetin acts as an antioxidant by inhibiting oxidative enzymes such as xanthine oxidase, lipoxygenase, and NADPH oxidase. Inhibition of these enzymes is also responsible for the attenuation of oxidative stress as they play key roles 
in the initial process of free radical-induced cellular damage [63]. It was recently reported that quercetin improved the antioxidants status in rats' testes and prevented spermatogonial cells from oxidative stress damage caused by reproductive toxicants $[64,65]$. In other way, a study reported by Michael et al. [66] showed that treatment of alloxan diabetic male rats with two diosmetin glycosides flavonoid compounds (diosmetin 7-O- $\beta$-L-arabinofuranosyl (1-2) $\beta$-D-apiofuranoside and diosmetin 7-O- $\beta$-D-apiofuranoside) isolated from the epicarp of date fruits, increased significantly serum testosterone level accompanied with highly significant decrease in total and prostatic acid phosphatase activities. Moreover, date fruit contains melatonin [67]. Melatonin is soluble in both lipid and aqueous environments and can readily cross the blood-testes barrier to protect the germinal epithelium [1]. A study reported by Rao \& Bhatt [68] showed that melatonin significantly protects the gonadal function against fluoride induced testicles toxicity in rat model. This effect was attributed to its free-radical scavenging actions beyond its stimulatory effects on antioxidant enzyme systems.

\section{Conclusion}

The present study indicates that low and high doses of DCA induced testicular toxicity in male rats. The pretreatment of DCA-intoxicated groups with ADE restored the lipid peroxidation, the antioxidant enzymes' status and the histoarchitecture of DCA-damaged testes. The protective effect of ADE may be due to its antioxidant property and detoxification capacity.

\footnotetext{
Abbreviations

ADE: Aqueous date extract; CAT: Catalase; DCA: Dichloroacetic acid; FSH: Follicle-stimulating hormone; GPX: Glutathione peroxidase; GSH: Glutathione; LH: Luteinizing hormone; LPO: Lipid peroxidation; MDA: Malondialdehyde; NBT: Nitrobluetetrazolium; ROS: Reactive oxygen species; SOD: Superoxide dismutase
}

\section{Funding}

No funding was obtained for this study.

\section{Availability of data and materials}

The datasets analyzed during the current study are available from the corresponding author on reasonable request.

\section{Author's contributions}

AEA developed the concepts, designed and carried out the experiments and was a major contributor in writing the manuscript. LH, AT, FG and BS contributed in carrying out the experiment design and in the analysis of oxidative stress parameters. FN analyzed and interpreted the rat data regarding the hematological disease. ZH performed the histological examination of the testes. LA revised the study proposal and approved the final version to be published. The manuscript was written through contributions of all authors. All authors have given approval to the final version of the manuscript.

\section{Competing interests}

The authors declare that they have no competing interests.

\section{Consent for publication}

The manuscript does not contain any individual person's data in any form. So, this information is not relevant

\section{Ethics approval and consent to participate}

Experiments were carried out in accordance with the guidelines of the Tunisian Society for the Care and Use of Laboratory Animals, and the study was approved by the University of Tunisia Ethical Committee (approval number: FST/ LNFP/Pro 152012).

\section{Author details}

'Laboratory of Bioressources, Biology Integrative and Valorization, Higher Institute of Biotechnology of Monastir, University of Monastir, Avenue Tahar Hadded, BP 74, 5000 Monastir, Tunisia. 'Laboratory of Histology and Cytogenetic, Faculty of Medicine, University of Monastir, Monastir 5019, Tunisia. ${ }^{3}$ Department of Biochemistry-Toxicology, Fattouma Bourguiba University Hospital, Monastir, Tunisia.

Received: 3 September 2016 Accepted: 28 February 2017

Published online: 22 April 2017

\section{References}

1. Aitken RJ, Roman SD. Antioxidant systems and oxidative stress in the testes. Oxid Med Cell Longev. 2008;1:15-24.

2. Saradha B, Mathur PP. Effect of environmental contaminants on male reproduction. Environ Toxicol Pharmacol. 2006;21:34-41.

3. Raymer J, Pellizari E, Childs B, Briggs K, Shoemaker J. Analytical methods for water disinfection byproducts in foods and beverages. J Expo Anal Environ Epidemiol. 2000;10:808-15.

4. Wu WW, Benjamin MM, Korshin GV. Effects of thermal treatment on halogenated disinfection byproducts in drinking water. Water Res. 2001;35:3545-50.

5. Mori M, Yamagata T, Goto T, Saito S, Momoi MY. Dichloroacetate treatment for mitochondrial cytopathy: Long-term effects in MELAS. Brain Dev. 2004;26:453-8.

6. Spruijt L, Naviaux RK, McGowan KA, Nyhan WL, Sheehan G, Haas RH, et al. Nerve conduction changes in patients with mitochondrial diseases treated with dichloroacetate. Muscle Nerve. 2001;24:916-24.

7. Katz R, Tai CN, Diener RM, McConnell RF, Semonick DE. Dichloroacetate, sodium: 3-month oral toxicity studies in rats and dogs. Toxicol Appl Pharmacol. 1981;57:273-87.

8. Yount EA, Felten SY, O'Connor BL, Peterson RG, Powell RS, Yum MN, et al. Comparison of the metabolic and toxic effects of 2-chloropropionate and dichloroacetat. J Pharmacol Exp Ther. 1982;222:501-8.

9. Toth GP, Kelty KC, George EL, Read EJ, Smith MK. Adverse male reproductive effects following subchronic exposure of rats to sodium dichloroacetate. Fundam Appl Toxicol. 1992;19:57-63.

10. Linder RE, Klinefelter GR, Strader LF, Suarez JD, Roberts NL. Spermatotoxicity of dichloroacetic acid. Reprod Toxicol. 1997;11:681-86.

11. Yousef Ml, Ismail AM, Baghdadi HH. Effect of isoflavones on reproductive performance, testosterone levels, lipid peroxidation and seminal plasma biochemistry of male rabbits. J Environ Sci Health B. 2004;39:819-33.

12. Yang HS, Han DK, Kim JR, Sin JC. Effect of a-tocopherol on cadmium induced toxicity in rat testes and spermatogenesis. J Korean Med Sci. 2006:21:445-51.

13. Nagda G, Bhatt DK. Alleviation of lindane induced toxicity in testes of swisse mice (Mus musculus) by combined treatment with vitamin C, vitamin $\mathrm{E}$ and a-lipoic acid. Indian J Exp Biol. 2011;49:191-9.

14. Kalender Y, Kaya S, Durak D, Uzun FG, Demir F. Protective effects of catechin and quercetin on antioxidant status, lipid peroxidation and testeshistoarchitecture induced by chlorpyrifos in male rats. Environ Toxicol Pharmacol. 2012;332:141-8.

15. Dzobo K, Naik YS. Effect of selenium on cadmium-induced oxidative stress and esterase activity in rat organs. South Afr J Sci. 2013;5:1-8.

16. Baliga MS, Baliga BRV, Kandathil SM, Bhat HP, Vayalil PK. A review of the chemistry and pharmacology of the date fruits (Phoenix dactylifera L.). Food Res Int. 2011;44:1812-22.

17. Rahmani AH, Aly SM, Ali H, Babiker AY, Srikar S, Khan AA. Therapeutic effects of date fruits (Phoenix dactylifera) in the prevention of diseases via modulation of anti-inflammatory, anti-oxidant and anti-tumour activity. Int J Clin Exp Med. 2014;7:483-91. 
18. Zohary D, Hopf M. Date palm, Phoenix dactylifera. In: Domestication of plants in the Old World. 2nd ed. Oxford: Clarendon; 1993. p. 157-62.

19. Ahmed MB, Hasona NAS, Selemain HAH. Protective effects of extract from dates (Phoenix dactylifera L.) and ascorbic acid on thioacetamide-induced hepatotoxicity in rats. Iran J Pharm Res. 2008;7:193-201.

20. Akunna GG, Saalu CL, Ogunmodede OS, Ogunlade B, Bello AJ. Aqueous extract of date fruit (Phoenix dactylifera) protects testes against atrazineinduced toxicity in rat. World J Life Sci Med Res. 2012;2:100-8.

21. El-Neweshy MS, El-Maddawy ZK, El-Sayed YS. Therapeutic effects of date palm (Phoenix dactylifera L.) pollen extract on cadmium-induced testicular toxicity. Androl. 2013;45:369-78.

22. El-kott AF, Sayed AA, El-Sayad SM, Abdoulrahman MH. The pharmaceutical effect of date palm fruit extract (Phoenix dactylifera L.) against amitraz-induced infertility in male rats. Adv Life Sci Technol. 2014;22:14-26.

23. Orabi SH, Shawky SM. Effect of date palm (Phoenix dactylifera) seeds extracts on hematological, biochemical parameters and some fertility indices in male rats. Int J Sci Basic Appl Res. 2014;17:137-47.

24. DeAngelo $A B$, George $M H$, House DE. Hepatocarcinogenicity in the male B6C3F1 mouse following a lifetime exposure to dichloroacetic acid in the drinking water: Dose-response determination and modes of action. J Toxicol Environ Health. 1999:58:485-507.

25. Daniel FB, DeAngelo AB, Stober JA, Olson GR, Page NP. Hepatocarcinogenicity of chloral hydrate, 2-chloroacetaldehyde, and dichloroacetic acid in the male B6C3F1 mouse. Fund Appl Toxicol. 1992;19:159-68.

26. Al-Qarawi AA, Mousa HM, Hamed-Ali BE, Abdel-Rahman H, El-Mougy SA. Protective effect of extracts from dates (Phoenix dactylifera L.) on carbon tetrachloride-induced hepatotoxicity in rats. Int J Appl Res Vet Med. 2004;2:176-80.

27. Bradford MM. A rapid and sensitive method for the quantitation of microgram quantities of protein utilizing the principle of protein-dye binding. Anal Biochem. 1976;72:248-54.

28. Beyer WE, Fridovich I. Assaying for superoxide dismutase activity: Some large consequences of minor changes in conditions. Anal Biochem. 1987;161:559-66.

29. Aebi H. Catalase in vitro. Methods Enzymol. 1984;105:121-6.

30. Flohe L, Gunzler WA. Assays of glutathione peroxidase. Methods Enzymol. 1984;105:114-210.

31. Sedlak J, Lindsay RH. Estimation of total, protein-bound, and nonprotein sulfhydryl groups in tissue with Ellman's reagent. Anal Biochem. 1968;25:192-205.

32. Buege AJ, Aust ST. Microsomal lipid peroxidation. Methods Enzymol. 1978;52:302-10.

33. Nezelof C, Golle H. Technique Microscopique. Paris, France: Flammarison; 1972.

34. Cicmanec JL, Condie LW, Olson GR, Wang SR. 90-day toxicity study of dichloroacetate in dogs. Fundam Appl Toxicol. 1991;17:376-89.

35. DeAngelo AB, Daniel FB, Most BM, Olson GR. The carcinogenicity of dichloroacetic acid in the male Fischer 344 rat. Toxicol. 1996;114:207-21.

36. Takahashi O, Oishi S. Testicular toxicity of dietary 2,2-bis(4-hydroxyphenyl) propane (bisphenol A) in F344 rat. Arch Toxicol. 2001;75:42-51.

37. Xie B, Li J, Zhu W. Pathological changes of testicular tissue in normal adult mice: A retrospective analysis. Exp Ther Med. 2014;7:654-6.

38. MacLachlan Rl, Meachem SJ, Stanton PG. deKretser DM, Pratis K, Robertson DM Identification of specific sites of hormonal regulation in spermatogenesis in rats, monkey, and man. Recent Prog Horm Res. 2002;57:149-79.

39. Spaliviero JA, Jimenez $M$, Allan CM, Handelsman DJ. Luteinizing hormone receptor-mediated effects on initiation of spermatogenesis in gonadotropin-deficient (hpg) mice are replicated by testosterone. Biol Reprod. 2004:70:32-8.

40. Potter $C L$, Chang LW, DeAngelo AB, Daniel FB. Effects of four trihalomethanes on DNA strand breaks, renal hyaline droplet formation and serum testosterone in male F-344 rats. Cancer Lett. 1996;106:235-42.

41. Sanghamitra S, Hazra J, Upadhyay SN, Singh RK, Amal RC. Arsenic induced toxicity on testicular tissue of mice. Indian J Physiol Pharmacol. 2008;52:84-90.

42. Akingbemi BT, Sottas CM, Koulova Al, Klinefelter GR, Hardy MP. Inhibition of testicular steroidogenesis by xenoestrogens bisphenol $\mathrm{A}$ is associated with reduced pituitary luteinizing hormone secretion and decreased steroidogenic enzymes gene expression in rat Leydig cells. Endocrinol. 2004;145:592-603.

43. Murugesan P, Muthusamy T, Balasubramanian K, Arunakaran J. Effects of vitamins $C$ and $E$ on steroidogenic enzymes mRNA expression in polychlorinated biphenyl (Aroclor 1254) exposed adult rat Leydig cells. Toxicol. 2007;232:170-82
44. Klinefelter GR, Strader LF, Suarez JD, Roberts NL. Bromochloroacetic acid exerts qualitative effects on rat sperm: implications for a novel biomarker. Toxicol Sci. 2002;68:164-73.

45. El Arem A, Thouri A, Zekri M, Saafi EB, Ghrairi F, Zakhama AF, et al. Nephroprotective effect of date fruit extract against dichloroacetic acid exposure in adult rats. Food Chem Toxicol. 2014;65:177-84.

46. El Arem A, Ghrairi F, Lahouar L, Thouri A, Saafi EB, Ayed A, et al. Hepatoprotective activity of date fruit extracts against dichloroacetic acidinduced liver damage in rats. J Funct Foods. 2014;9:119-30.

47. Halliwell B, Gutteridge JMC. Free Radicals in Biology and Medicine. second reprint. Oxford: Clarendon; 1989. p. 543.

48. Peltola V, Huhtaniemi I, Ahotupa M. Antioxidant enzyme activity in the maturing rat testes. J Androl. 1992;13:450-5.

49. Cheung CCC, Zheng GJ, Li AMY, Richardson BJ, Lam PKS. Relationship between tissue concentrations of polycyclic aromatic hydrocarbons and antioxidative responses of marine mussels Perna viridis. Aquat Toxicol. 2001;52:189-203.

50. Braga AL, Alberto EE, Soares LC, Rocha JBT, Sudati JH, Roos DH. Synthesis of telluroamino acid derivatives with remarkable GPx like activity. Org Biomol Chem. 2009;7:43-5.

51. Freeman BA, Crapo JD. Hyperoxia increases oxygen radical production in rat lung and lung mitochondria. J Biol Chem. 1981;256:10986-92.

52. Mathur PP, D'Cruz SC. The effect of environmental contaminants on testicular function. Asian J Androl. 2011:13:585-91.

53. Sumedha NC, Miltonprabu S. Diallyl trisulfide (DATS) abrogates arsenic induced testicular oxidative stress in rats. Int J Pharmacol Toxicol. 2014;2:30-7.

54. Sharma P, UI Huq A, Singh R. Cypermethrin-induced reproductive toxicity in the rat is prevented by resveratrol. J Hum Reprod Sci. 2014;7:99-107.

55. Nithya R, Elango V. Pesticide effect in male hormones and antioxidant status in male albino rats. J Acad Indus Res. 2015;4:140-3.

56. El-Mougy SA, Abdel-Aziz SA, Al-Shanawany M, Omar A. The gonadotropic activity of Palmae in mature male rats. Alexandria J Pharmac Sci. 1991;5:156-9.

57. Bray TM, Bettger WJ. The physiological role of zinc as an antioxidant. Free Radic Biol Med. 1990;8:281-91

58. Shaban El-Neweshy M, Said E-SY. Influence of vitamin C supplementation on lead-induced histopathological alterations in male rats. Exp Toxicol Pathol. 2011:63:221-7.

59. Paolicchi A, Pezzini A, Saviozzi M, Piaggi S, Andreuccetti M, Chieli E, et al. Localization of a GSH-dependent dehydroascorbate reductase in rat tissues and subcellular fractions. Arch Biochem Biophys. 1996:333:489-95.

60. Johnson FC. The antioxidant vitamins. CRC Crit Rev Food Sci Nutr. 1979;1:217-309.

61. Garcia OB, Castillo J. Update on uses and properties of citrus flavonoids: new findings in anticancer, cardiovascular, and anti-inflammatory activity. J Agric Food Chem. 2008;56:6185-205.

62. Hong YJ, Tomas-Barberan FA, Kader AA, Mitchell AE. The flavonoid glycosides and procyanidin composition of Deglet Noor dates (Phoenix dactylifera). J Agric Food Chem. 2006;54:2405-11.

63. Day AJ, Canada FJ, Diaz JC, Kroon PA, Mclauchlan R, Faulds CB, et al. Dietary flavonoid and isoflavone glycosides are hydrolysed by the lactase site of lactase phlorizin hydrolase. FEBS Lett. 2000;468:166-70.

64. Tong-liang BU, Yu-dong JIA, Jin-xing LIN, Yu-ling MI, Cai-qiao Z. Alleviative effect of quercetin on germ cells intoxicated by 3-methyl-4-nitrophenol from diesel exhaust articles. J Zhejiang Univ-Sci B). 2012;13:18-326.

65. Sonmez M, Turk G, Ceribasi S, Ciftci M, Yuce A, Guvenc M, et al. Quercetin attenuates carbon tetrachloride-induced testicular damage in rats. Androl. 2014:46:848-58

66. Michael HN, Salib JY, Eskander EF. Bioactivity of diosmetin glycosides isolated from the epicarp of date fruits, Phoenix dactylifera, on the biochemical profile of alloxan diabetic male rats. Phytother Res. 2013;27: 699-704.

67. Al-Qarawi AA, Ali BH, Al-Mougy SA, Mousa HM. Gastrointestinal transit in mice treated with various extracts of date (Phoenix dactylifera L.). Food Chem Toxicol. 2003;41:37-9.

68. Rao MV, Bhatt RN. Protective effect of melatonin on fluoride-induced oxidative stress and testicular dysfunction in rats. Res Report Fluoride 2012:45:116-24 